\title{
Antibacterial and cytotoxic activities of supernatant and mycelium extracts from fermentation of fungal symbiont Trichoderma reesei TV221
}

\author{
Putu Oka Samirana ${ }^{1,2}$ (D), Yosi Bayu Murti ${ }^{3}$ (D), Riris Istighfari Jenie ${ }^{4}$ (D), Erna Prawita Setyowati ${ }^{5 *}$ (D) \\ ${ }^{1}$ Doctoral Program in Pharmaceutical Science, Faculty of Pharmacy, Universitas Gadjah Mada, Yogyakarta, Indonesia. \\ ${ }^{2}$ Department of Pharmacy, Faculty of Mathematics and Natural Science, Udayana University, Bali, Indonesia. \\ ${ }^{3}$ Department of Pharmaceutical Biology, Faculty of Pharmacy, Universitas Gadjah Mada, Yogyakarta, Indonesia. \\ ${ }^{4}$ Department of Pharmaceutical Chemistry, Faculty of Pharmacy, Universitas Gadjah Mada, Yogyakarta, Indonesia. \\ ${ }^{5}$ Department of Pharmaceutical Biology, Faculty of Pharmacy, Universitas Gadjah Mada, Yogyakarta, Indonesia.
}

\section{ARTICLE INFO \\ Received on: 07/06/2021 \\ Accepted on: 31/08/2021 \\ Available Online: 05/12/2021}

\section{Key words:}

Trichoderma reesei, antibacterial, cytotoxic, fermentation, salinity.

\begin{abstract}
Fungi are microorganisms that can be in a symbiotic relationship with marine sponges in producing secondary metabolites. One of the sponge-associated fungi that have been studied and have antibacterial and cytotoxic activity is Trichoderma reesei TV221. This fungus comes from the Stylissa flabelliformis sponge from Menjangan Island, West Bali National Park, Bali. This study aimed to determine the growth curve of fungi fermented with seawater made from natural sea salt with a concentration of 30 parts per trillion (ppt), to be tested for antibacterial and cytotoxic activities on the mycelium and supernatant components of the fermentation, and to determine the selectivity index (SI). The growth curve was plotted by determining the dry weight of the mycelium every 2 days for 14 days of fermentation. The antibacterial activity of the extract was tested against Escherichia coli American Type Culture Collection (ATCC) 25922 and Staphylococcus aureus ATCC 25923, while the cytotoxic activity was tested against the WiDr cancer cell line and Vero cell line. The results showed that the maximum growth of T. reesei TV221 fungi took place on day 12. The mycelium and supernatant extracts from the fermentation had a potential antibacterial activity, especially against S. aureus ATCC 25923, especially fermentation on days 6 and 12. The supernatant extracts on days 12 and 14 had potential cytotoxic activity against the WiDr cancer cell line and had an SI value $>3$. Based on the antibacterial and cytotoxic activities, it is likely that the active metabolites of the T. reesei TV221 fungus began to be produced on day 2 and reached their peak on day 12 . The active metabolites contributing to the antibacterial and cytotoxic activities were estimated to be cyclohexanone, phenol, and terpenoid groups.
\end{abstract}

\section{INTRODUCTION}

Marine sponges are marine organisms from the phylum Porifera whose life is in symbiosis with various microbes, including bacteria, cyanobacteria, microalgae, and fungi. The microbial symbiosis in some marine sponges can reach $60 \%$ of their body weight and contributes significantly to the metabolism

\footnotetext{
*Corresponding Author

Erna Prawita Setyowati, Department of Pharmaceutical Biology, Faculty of Pharmacy, Universitas Gadjah Mada, Yogyakarta, Indonesia.

E-mail:erna_prawita@ugm.ac.id
}

of these sponges (Brinkmann et al., 2017; Taylor et al., 2007). The association between symbionts and marine sponges has enormous potential in health science, especially in the discovery of new medicinal substances derived from natural products. The results of combining marine sponges with symbionts as secondary metabolites demonstrate potential bioactivity as an antimicrobial or antibacterial agent, antitumor agent, cytotoxic agent, inhibitor of cell division, and inhibitor or enzyme inhibitor (Suman et al., 2013; Thoms et al., 2007). Several active metabolites, such as jasplakinolide, bryostatin, and microluside $\mathrm{A}$, seem to be produced by microbial symbionts found in marine sponges (Egan et al., 2008; Eltamany et al., 2014; Rungprom et al., 2008). 
As a result, symbionts derived from microbial sponges can be cultured and isolated to increase the production of some spongederived metabolite compounds (Lee et al., 2001). Fungi are microorganisms that can work together with sponges to produce secondary metabolites. In order to survive in these conditions, the sponge association function will produce secondary metabolites which are probably bioactive compounds for medicines. It is necessary to investigate the possibility of increasing the number of medicinal products derived from marine resources (Debbab et al., 2011; Shalini et al., 2014).

One of the sponge-associated fungi that have been researched and have antibacterial and cytotoxic activity is $T$. reese $i$ TV221 (Setyowati et al., 2017, 2018a, 2018b). This fungus is a sponge-associated fungus from the Stylissa flabelliformis marine sponge from Menjangan Island, West Bali National Park. The marine sponge $S$. flabelliformis was previously known to have antimicrobial and cytotoxic activities (Setyowati et al., 2005; Setyowati et al., 2021). The extract from the fermentation of the T. reesei TV221 fungi associated with the $S$. flabelliformis sponge has antimicrobial activity against Staphylococcus aureus American Type Culture Collection (ATCC) 29213, Escherichia coli ATCC 25922, Candida albicans ATCC 10231, and methicillin-resistant S. aureus (Setyowati et al., 2017). The extract also has cytotoxic activity on cancer cell lines WiDr, 4T1, T47D, and Raji, with the best cytotoxic activity on WiDr cells, and has the highest selectivity index (SI) compared to the Vero cell line (normal cells) (Setyowati et al., 2018a, 2017). According to the results of previous studies, the fungus $T$. reese $i$ TV221 associated with the sponge $S$. flabelliformis could be developed as an antibacterial and anticancer agent.

In previous research, only the supernatant extract from the fermentation of the fungus $T$. reesei TV221 was tested for antibacterial and cytotoxic activities. In this research, antibacterial and cytotoxic activity tests were carried out on the mycelium components from the fermentation of the $T$. reesei TV221 fungus and the growth curve of fungi fermented with seawater made from natural sea salt with a concentration of $30 \mathrm{ppt}(3 \%)$ was determined.

\section{MATERIALS AND METHODS}

\section{Materials}

Trichoderma reesei TV221, a fungal symbiont from the $S$. flabelliformis sponge, was from Menjangan Island, West National Park, Bali. Also used were sabouraud dextrose agar (SDA) (Oxoid) and sabouraud dextrose broth (SDB) (Oxoid). Microbial tests used in the study were E. coli ATCC 25922, S. aureus ATCC 25923, nutrient agar (NA) (Oxoid), and nutrient broth (Oxoid). WiDr cancer cells line and Vero cells line were sourced from the Cancer Chemoprevention Research Center Universitas Gadjah Mada. Other materials used were MTT solution (Sigma-Aldrich), phosphatebuffered saline (PBS) (Sigma-Aldrich), fetal bovine serum (Sigma), penicillin-streptomycin (Gibco, Invitrogen Canada), Roswell Park Memorial Institute 1640, trypsin-EDTA (Gibco, Invitrogen Canada), sodium dodecyl sulfate (SDS) (Merck Schuchardt, Germany), 5-fluorouracil (Sigma-Aldrich), and Microplate 96 (IWAKI).

\section{Equipment}

The equipment used included the following: inverted microscope (Olympus ${ }^{\circledR}$, Japan), $\mathrm{CO}_{2}$ incubator (Heraeus $^{\circledR}$, Germany), Cytotoxic Safety Cabinet (ESCO ${ }^{\circledR}$, type Cytoculture),
Haemocytometer (Assistet $\left.{ }^{\circledR}\right)$, vacuum evaporator $\left(\right.$ Heidolph $\left.^{\circledR}\right)$, microplate reader $\left(\right.$ Bio-Rad $^{\circledR}$, Japan), and. ELISA reader (ELx, $\left.\operatorname{BioTech}^{\circledR}\right)$.

\section{Cultivation, fermentation, and extraction of fungal metabolites}

The $T$. reesei TV221 fungal isolate associated with the $S$. flabelliformis sponge was used in a previous study and stored at the Indonesian Center for Biodiversity and Biotechnology Bogor for recultivation (Setyowati et al., 2018b). The fungal isolates were transferred to the SDA medium. A Petri dish was incubated at ambient temperature for 7 days (Setyowati et al., 2017). To produce secondary metabolites, fermentation was carried out with a liquid medium. The fungus was cultivated at $25^{\circ} \mathrm{C}$ for 14 days using SDB dissolved in seawater with a salinity of $30 \mathrm{ppt}$ (30 $\mathrm{g}$ of natural sea salt, $1,000 \mathrm{ml}$ of distilled water) to as much as $200 \mathrm{ml}$ for each fermentation flask and placed on a rotary shaker (120 rpm). Fermentation sampling was carried out every 2 days, followed by the separation of the supernatant and mycelium. The mycelium obtained was dried at $55^{\circ} \mathrm{C}$ for 3 days, followed by determining the dry weight of the mycelium, and then sonicated with ethyl acetate for 30 minutes three times. The supernatant was carried out by liquid extraction with ethyl acetate and the organic part was taken. The extract obtained from the supernatant and mycelium was then evaporated by rotary evaporation at $60^{\circ} \mathrm{C}$ until dry and the extract was then weighed.

\section{Antibacterial activity}

The bacteria used for the study were E. coli ATCC 25922 and $S$. aureus ATCC 25923 of which the concentration of bacteria was $10^{7} \mathrm{CFU}$ suspended on a $10 \mathrm{ml}$ NA medium. Ethyl acetate extracts from the supernatant and mycelium were made with a concentration of $10 \mathrm{mg} / \mathrm{ml}$ with methanol and $10 \mu \mathrm{l}$ of each was sprayed into a sterilized paper dish. As a positive control, chloramphenicol $1 \mathrm{mg} / \mathrm{ml}$ was used. As much as $10 \mu \mathrm{l}$ was sprayed into a sterilized paper dish. Each paper dish was placed on NA solid media which already contained a bacterial suspension. The Petri dish was incubated overnight at $37^{\circ} \mathrm{C}$. The inhibition zone that formed around the paper dish was observed (Niyomkam et al., 2010).

\section{Cytotoxic activity on WiDr Cancer cell line and Vero cell line}

Cancer cells were prepared in a concentration of $10^{4}$ cells for each well in 96-well plates. The cell line was incubated for 24 hours in a $37^{\circ} \mathrm{C} \mathrm{CO}_{2}$ incubator. Following incubation, the medium was removed and washed using $100 \mu \mathrm{l}$ PBS solution/well. Samples with seven variations of concentration $(7.81,15.62,31.25,62.5$, 125,250 , and $500 \mu \mathrm{g} / \mathrm{ml}$ ) and 5-fluorouracil control were put into the 96-well plates, each of which was $100 \mu \mathrm{l} /$ well. It was incubated again in a $37^{\circ} \mathrm{C} \mathrm{CO}_{2}$ incubator for a period of 48 hours. Samples and control were removed, the well was washed using $100 \mu 1 \mathrm{PBS} /$ well twice, and then a $100 \mu \mathrm{l} /$ well MTT solution was then added to each well and incubated for 4 hours in a $37^{\circ} \mathrm{C} \mathrm{CO}$ incubator. The formation of formazan crystals was observed under an inverted microscope. After the formazan crystals were formed, a $100 \mu \mathrm{l} /$ well stopper reagent $(10 \% \mathrm{SDS}$ in $0.1 \mathrm{~N} \mathrm{HCl})$ was added and incubated at room temperature in the dark overnight. The cell density was determined by absorbance reading using an ELISA 
reader at a wavelength of $550 \mathrm{~nm}$ (Cancer Chemoprevention Research Center, 2019; Janakiraman et al., 2020; Setyowati et al., 2018a; Sharmalkumar et al., 2020). The percentage of viable cells was calculated by the following formula:

$$
\begin{gathered}
\text { Percentage of } \\
\text { viable cell }(\%)
\end{gathered}=\frac{(\text { Abs sample }- \text { Abs media })}{(\text { Abs normal }- \text { Abs media })} \times 100
$$

\section{Calculation of SI}

The $\mathrm{SI}$ is the value of $\mathrm{IC}_{50}$ in a normal cell line $/ \mathrm{IC}_{50}$ in a cancer cell line, where $\mathrm{IC}_{50}$ is a concentration capable of killing $50 \%$ of the cell population. The sample under study was said to have high selectivity if it had a value of SI $\geq 3$ (Sutejo et al., 2016). The SI was determined by the following formula:

$$
\mathrm{SI}=\frac{\left.\mathrm{IC}_{50} \text { on normal cell (Verso Cells }\right)}{\mathrm{IC}_{50} \text { on cancer cell }(\text { WiDr Cells })} \times 100
$$

\section{RESULTS AND DISCUSSION}

Trichoderma reesei TV221 is a fungal symbiont of the S. flabelliformis marine sponge obtained from Menjangan Island, North Bali. The results of the fermentation of the T. reesei TV221 fungus on SDB medium with seawater for 11 days were known to have antibacterial and cytotoxic activity against several cancer cell lines (Setyowati et al., 2017, 2018a, 2018b). However, previous studies neither revealed when the secondary metabolites began to be produced nor determined the salinity level of the seawater used. To determine these, in this study, in obtaining the secondary metabolites from the $T$. reesei TV221 fungus, the fungal culture was fermented in liquid media of SDB with seawater made from natural sea salt with a concentration of $30 \mathrm{ppt}$ and fermented samples were taken every 2 days, followed by the determination of antibacterial and cytotoxic activity on the WiDr cancer cell line.

The life phase of the fungus can be described by the growth curve observed from sampling every 2 days during fermentation. The growth curve of $T$. reesei TV221 is shown in Figure 1 (a). Trichoderma reesei TV221 passes through the log phase on days $4-10$, while the stationary phase starts from days 10 to 12 which is followed by a declination phase from day 12 . The highest dry weight of mycelium was produced on day $12(1,062$ $\mathrm{mg}$ ). Fungi and microorganisms in general will produce secondary metabolites in the stationary phase. The fungus associated with the Cinachyrella sp. sponge, T. reesei, was reported to have a growth curve similar to the stationary phase that occurs around day 12 (Sibero et al., 2018). In previous studies, T. reesei showed the highest antibacterial activity in the fermentation on days 11-12 (Setyowati et al., 2017). The nutrient content of the fungal growth media in solid and liquid greatly affects the growth of fungi. In producing bioactive metabolites, a fermentation medium is essential. Sources

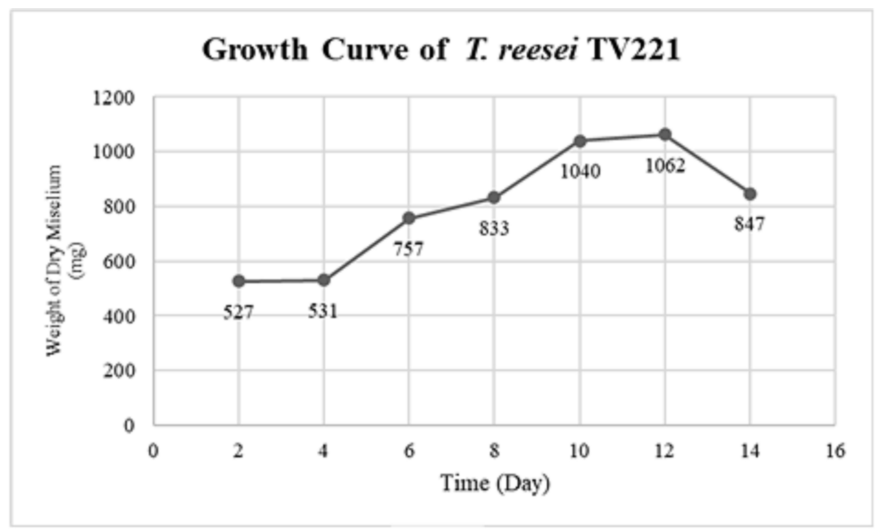

(a)

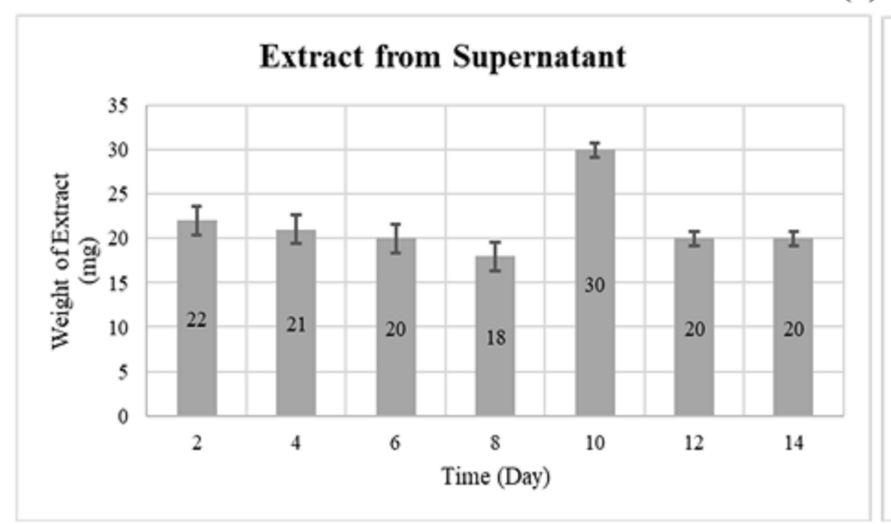

(b)

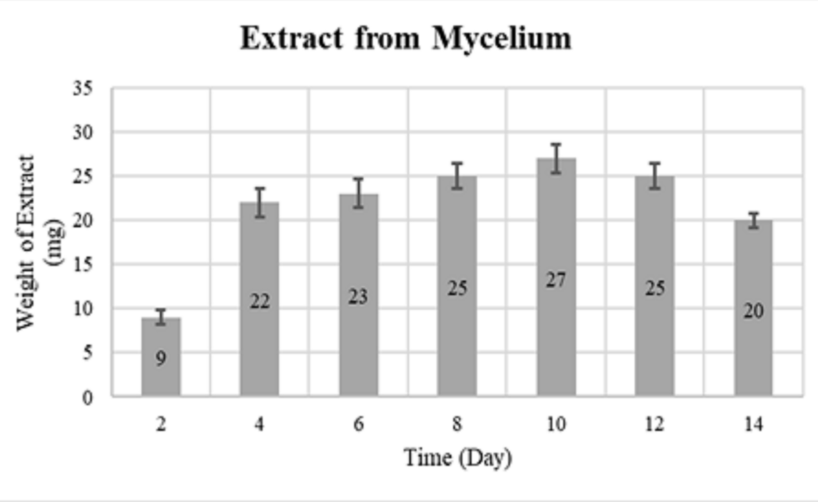

(c)

Figure 1. (a) Growth curve of fungal T. reesei TV221; (b) Weights of the extract from the supernatant; and (c) Weights of the extract from mycelium. 


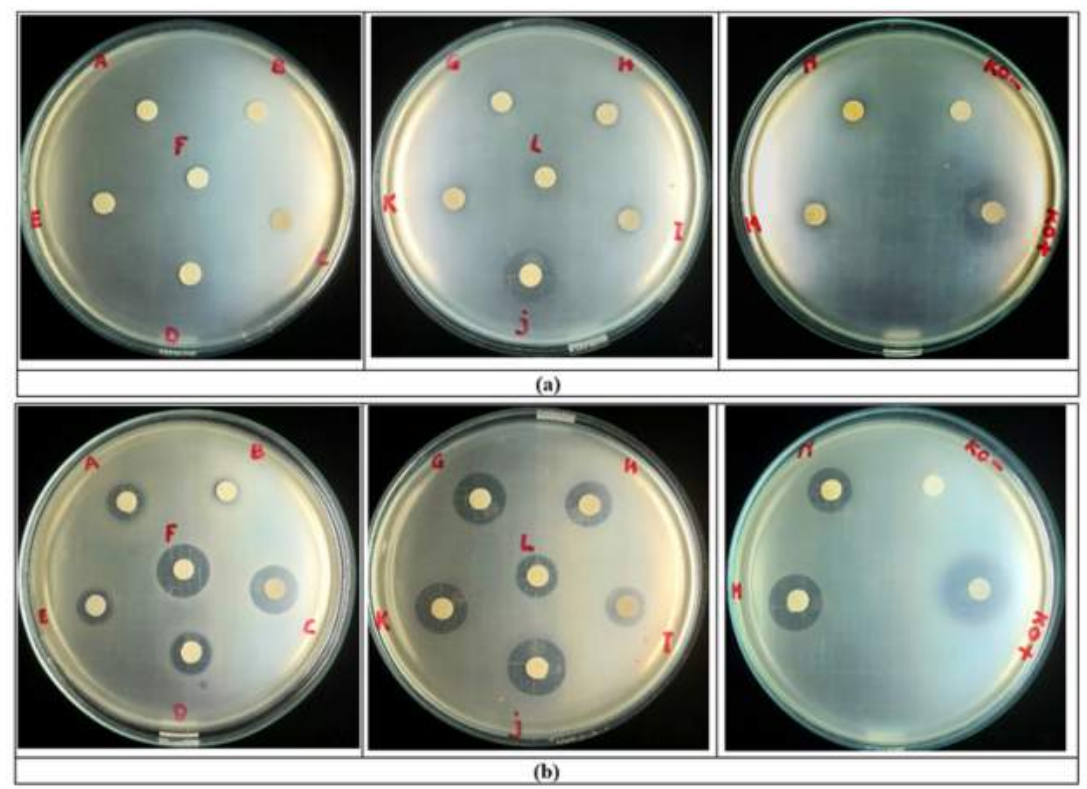

Figure 2. Antibacterial effect of the extracts from mycelium (sample codes $A-G$ ) and supernatant ( sample codes $\mathrm{H}-\mathrm{N}) ;(\mathrm{KO}-)$ = negative control; $(\mathrm{KO}+)=$ positive control. (a) Escherichia coli $\mathrm{ATCC}$ 25922; (b) Staphylococcus aureus ATCC 25923.

of carbon, nitrogen, and salinity are factors in the production of bioactive metabolites from marine sponge symbionts, especially fungi (Samirana et al., 2020; Ukhty et al., 2017). In Figure 1 (b) and (c), the weight of the extracts derived from the supernatant and mycelium resulting from the fermentation is presented. The highest weight of both supernatant and mycelium extracts occurred on day 10 of fermentation. This is possible because the T. reesei TV221 fungus entered a stationary phase where the fungus began to maximally produce secondary metabolites (Stanbury et al., 1995).

In previous research, the $T$. reesei TV221 fungus was known to have antibacterial activity on S. aureus ATCC 29213 and E. coli ATCC 25922 (Setyowati et al., 2017, 2018b). The samples of the study were only the supernatant extract from the fermentation results and the fermentation was carried out with seawater whose concentration was unknown. In this study, the tests were carried out on the supernatant and mycelium extracts with a seawater concentration of $30 \mathrm{ppt}$. The results of the antibacterial activity test of the supernatant and mycelium extract fermented on days 2-14 are shown in Figure 2. The potential antibacterial activity of the supernatant and mycelium extracts was shown against $S$. aureus ATCC 25923 as a representation of Grampositive bacteria starting on day 2 of the fermentation. The highest antibacterial activity of the supernatant extract against $S$. aureus ATCC 25923 occurred on days 6 and 12 of the fermentation, while that of the mycelium extract occurred on days 6 and 12 of the fermentation. This shows that the antibacterial active components were released from the fungal cells maximally on days 6 and 12 into the supernatant and maximally accumulated in the fungal cells on days 6 and 12. Previous research also showed the same phenomenon, in which the highest antibacterial activity against $S$. aureus from the supernatant extract of $T$. reesei TV221 fungi occurred on days 6 and 12 of the fermentation (Setyowati et al., 2017). The antibacterial activity against $E$. coli ATCC 25922 from the supernatant and mycelium extracts from the fermentation of
T. reesei TV221 fungi with seawater at a concentration of $30 \mathrm{ppt}$ showed lower results than the activity against $S$. aureus ATCC 25923. The mycelium extracts only showed activity against $E$. coli ATCC 25922 on days 10 and 12 of the fermentation, while the supernatant extracts showed the highest activity against $E$. coli ATCC 25922 on day 6 of the fermentation. The antibacterial activity of the supernatant extract on day 6 is in line with the results of previous studies (Setyowati et al., 2017). The reduced antibacterial activity of the supernatant and mycelium extracts from the fermentation of the $T$. reesei TV221 fungus against $E$. coli ATCC 25922 as a representation of Gram-negative bacteria is possible because the salinity levels were different from previous studies. Several species of the genus Trichoderma fungi were reported to have high sensitivity to environmental salinity, which can affect the growth and production of secondary metabolites resulting in biological activity (Bheemaraya et al., 2013; Mishra et al., 2016; Samirana et al., 2020).

The diameter of the inhibition zone in the antibacterial test against E. coli ATCC 25922 and S. aureus ATCC 25923 can indicate the ability of the sample to inhibit microbial growth. An overview of the diameter of the inhibition zone is shown in Figure 3. The widest diameter of the inhibition zone in the study for the antibacterial activity against $E$. coli ATCC 25922 was shown by the supernatant extract on day $6(14.33 \mathrm{~mm})$, while the narrowest one was shown by the mycelium extract on days 10 and $12(6.67 \mathrm{~mm})$. The mycelium extract on days 2-8 and 14 and supernatant extracts on days 8 and 10 did not show any inhibition zone against $E$. coli ATCC 25922 bacteria. This shows that the supernatant extract was more active than the mycelium extract, where the supernatant extract from days 6 to 12 of the fermentation had the potential as an antibacterial agent against E. coli ATCC 25922, which represented Gram-negative bacteria. The widest diameter of the inhibition zone in the antibacterial test against S. aureus ATCC 25923 was shown by the supernatant extract on day $6(17.67 \mathrm{~mm})$ and the narrowest one was shown by the mycelium 


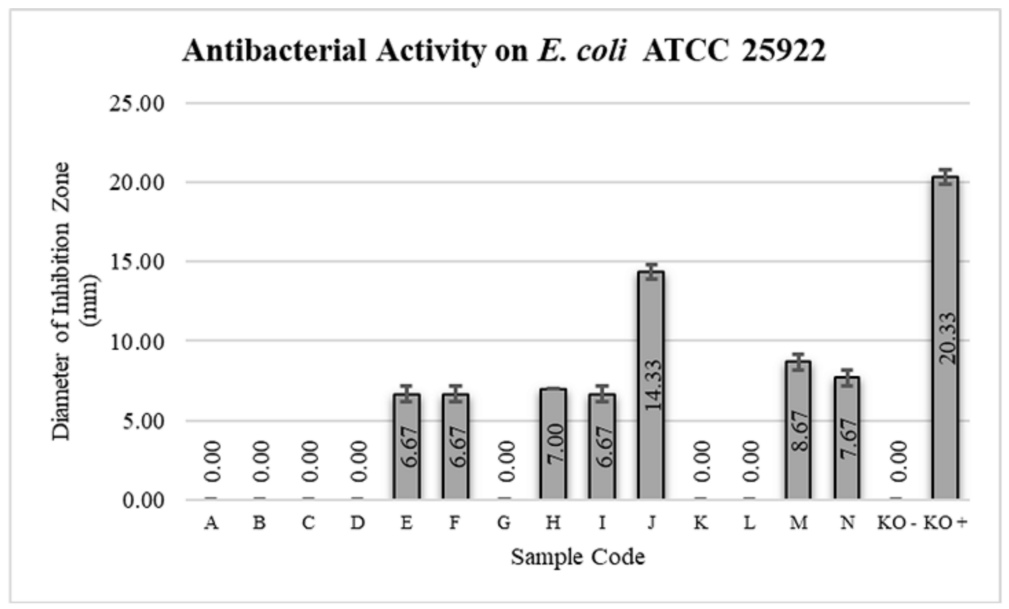

(a)

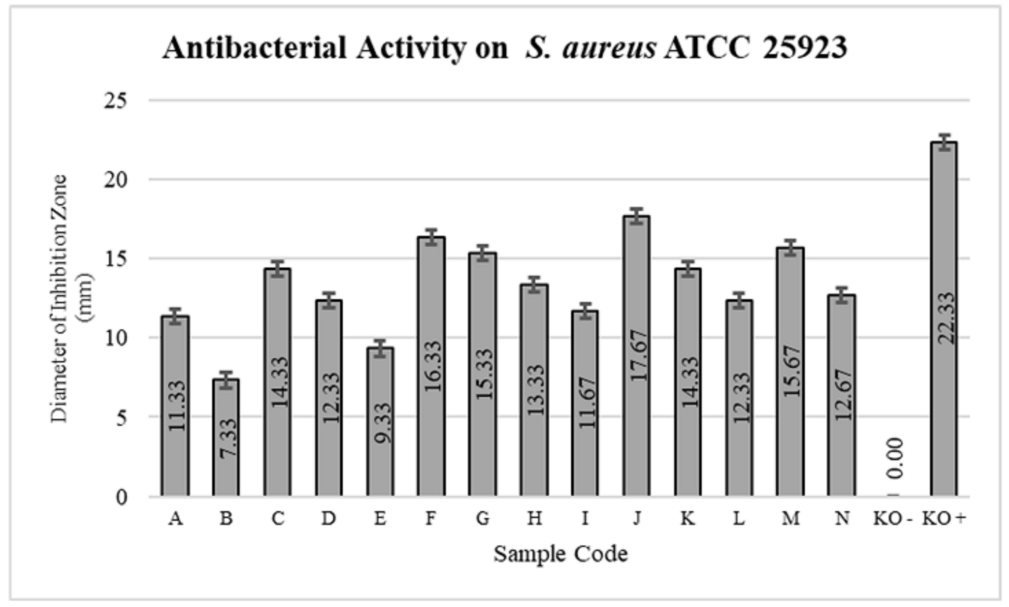

(b)

Figure 3. Value of the antibacterial inhibition zone diameter at (a) Escherichia coli ATCC 25922 and (b) Staphylococcus aureus ATCC 25923. Extracts from mycelium (sample codes $\mathrm{A}-\mathrm{G})$ and supernatant $($ sample codes $\mathrm{H}-\mathrm{N}) ;(\mathrm{KO}-)$ = negative control; $(\mathrm{KO}+)=$ positive control.

extract on day $4(7.33 \mathrm{~mm})$. All the supernatant and mycelium extracts showed antibacterial activity on S. aureus ATCC 25923 which represented Gram-positive bacteria. The mycelium extract on days 12 and 14 and the supernatant extract on days 6 and 12 had a wide inhibition zone diameter, so these extracts had the potential as an antibacterial agent against $S$. aureus ATCC 25923. Chloramphenicol, an antibiotic with a broad spectrum, was used as a positive control, which showed an inhibition zone diameter against $E$. coli ATCC 25922 and S. aureus ATCC 25923 of $20.33 \mathrm{~mm}$ and $22.33 \mathrm{~mm}$, respectively. The criteria for the inhibition zone diameter for antibacterial activity are as follows: inhibition zone diameter of $5 \mathrm{~mm}$ or less is categorized as having weak antibacterial activity, inhibition zone of $5-10 \mathrm{~mm}$ is categorized as having moderate antibacterial activity, inhibition zone of $10-20 \mathrm{~mm}$ is categorized as having strong antibacterial activity, and inhibition zone of $20 \mathrm{~mm}$ or more is categorized as having very strong antibacterial activity (Davis et al., 1971a, 1971b). Based on these criteria, the mycelium extracts on days 10 and 12 and the supernatant extracts on days 12 and 14 against $E$. coli ATCC 25922 were classified as having moderate antibacterial activity, and the supernatant extract on day 6 was classified as having strong antibacterial activity. The antibacterial activity against S. aureus ATCC 25923 from all the mycelium and supernatant extracts was strong, except the mycelium extracts on days 4 and 10 which were classified as moderate. The extract activity was shown to be more active against $S$. aureus ATCC 25923 compared to $E$. coli ATCC 25922 because $E$. coli ATCC 25922 which are Gram-negative bacteria have a cell wall structure that is more complex than $S$. aureus ATCC 25923 which are classified as Gram-positive bacteria (Pelczar et al., 2008a; Sangavi et al., 2019; Shahid et al., 2015). In the positive control, the inhibition zone was classified as having very strong antibacterial activity. In fact, this is natural considering the fact that chloramphenicol is a broad-spectrum antibiotic, so it is effective for both Gram-negative and Gram-positive bacteria (Tjay et al., 2015).

The type of inhibition zone in the antibacterial test using a disc can indicate the sensitivity of bacteria to antibacterial agents or antibiotics as test materials. The type of inhibition zone can be divided into a radical zone and an irradical zone. The radical zone type is indicated by a clear boundary between the bacterial colony and the clear zone that is not covered by the bacterial colonies, and this is usually called the kill zone type. The irradical zone 
Table 1. Inhibition of antibacterial activity on E. coli ATCC 25922 and S. aureus ATCC 25923.

\begin{tabular}{cccc}
\hline Sample code & Specimen & \multicolumn{2}{c}{ Inhibition type } \\
\cline { 3 - 4 } & & $\mathbf{2 5 9 2 2}$ & $\begin{array}{c}\text { Staphylococcus aureus } \\
\text { ATCC 25923 }\end{array}$ \\
\hline A & Mycelium day 2 & R.A & Radical \\
B & Mycelium day 4 & N.A & Irradical \\
C & Mycelium day 6 & N.A & Radical \\
D & Mycelium day 8 & N.A & Radical \\
E & Mycelium day 10 & Irradical & Radical \\
F & Mycelium day 12 & Irradical & Radical \\
G & Mycelium day 14 & N.A & Radical \\
H & Supernatant day 2 & Irradical & Radical \\
I & Supernatant day 4 & Irradical & Radical \\
J & Supernatant day 6 & Radical & Radical \\
K & Supernatant day 8 & N.A & Radical \\
L & Supernatant day 10 & N.A & Radical \\
M & Supernatant day 12 & Irradical & Radical \\
N & Supernatant day 14 & Irradical & Irradical \\
KO- & Negative control & N.A & N.A \\
KO+ & Positive control & Irradical & Irradical \\
\hline
\end{tabular}

N.A: Not active.

type is indicated by the presence of unclear or equal boundaries between the bacterial colony and the clear zone with bacterial overgrowth, usually referred to as the inhibition zone type (Pelczar et al., 2008a, 2008b; Balouiri et al., 2016). The type of the inhibition zone of the mycelium and supernatant extracts in the antibacterial test is presented in Table 1. Most of the inhibition zone against $E$. coli ATCC 25922 was of the irradical type and only one sample of the extract was categorized as the radical type in the supernatant extract on day 6. Therefore, the extract which is active as an antibacterial agent against E. coli ATCC 25922 has the potential to inhibit bacterial growth as seen from the type of inhibition zone. Most of the inhibition zone in the antibacterial test against $S$. aureus ATCC 25923 was categorized as the radical type and only two extract samples of the mycelium extract on day 4 and the supernatant extract on day 14 were categorized as the irradical inhibition zone type. Therefore, the extract which is active as an antibacterial agent against $S$. aureus ATCC 25923 has the potential to kill bacterial growth as seen from the type of inhibition zone.

The results of the cytotoxic test of the mycelium and supernatant extracts on the WiDr cell line are shown in Figure 4 , which showed the morphological photos of the WiDr cancer cell line given the treatment at the highest $(500 \mu \mathrm{g} / \mathrm{ml})$ and the lowest $(7.81 \mu \mathrm{g} / \mathrm{ml})$ concentrations. In the cell morphology image, in general, at the highest dose of treatment, the cancer cell line died which was marked by a round cell shape not attached to the surface. Treated at the lowest dose, the WiDr cancer cell line morphology looked like epithelial cells that were dilated and attached to the surface base, indicating the cell line was still alive (Fadholly et al., 2019; Proboningrat et al., 2021).

Cytotoxic activity is indicated by the value of the $\mathrm{IC}_{50}$ sample, which is the result of the calculation of the linear regression equation where the $x$-axis is the log of concentration and the $y$-axis is the percentage of cell viability. The smaller the value of $\mathrm{IC}_{50}$, the higher the potential of the sample to have cytotoxic activity. The largest $\mathrm{IC}_{50}$ value of the mycelium extract was on day $6(5,654.58$ $\mu \mathrm{g} / \mathrm{ml})$ and the smallest one was on day $14(205.63 \mu \mathrm{g} / \mathrm{ml})$. The supernatant extract had the largest $\mathrm{IC}_{50}$ value on day $2(255.61 \mu \mathrm{g} /$ $\mathrm{ml})$ and the smallest on day $12(81.72 \mu \mathrm{g} / \mathrm{ml})$. The $\mathrm{IC}_{50}$ value of the extract of natural ingredients can be classified into three levels of cytotoxic activity; namely, $\mathrm{IC}_{50}$ value $<10 \mu \mathrm{g} / \mathrm{ml}$ has a very strong cytotoxic effect, $\mathrm{IC}_{50}$ value $10-100 \mu \mathrm{g} / \mathrm{ml}$ has a strong cytotoxic effect, and $\mathrm{IC}_{50}$ value of $100-500 \mu \mathrm{g} / \mathrm{ml}$ has a moderate cytotoxic effect (Samirana et al., 2020; Weerapreeyakul et al., 2012). Based on the data presented in Table 2, generally the mycelium and supernatant extracts had cytotoxic activity on the WiDr cancer cell line which was classified as a moderate cytotoxic effect, except for the supernatant extract on days $12(81.72 \mu \mathrm{g} / \mathrm{ml})$ and $14(81.93 \mu \mathrm{g} /$ $\mathrm{ml}$ ) which had strong cytotoxic activity. The control (5-fluorouracil) had an $\mathrm{IC}_{50}$ value of $24.99 \mu \mathrm{g} / \mathrm{ml}$, which had strong cytotoxic activity on the WiDr cell line. 5-Fluorouracil is known to be the first line in the treatment of colon cancer, so this study used it as the control (Masi et al., 2006). The $\mathrm{IC}_{50}$ value of the supernatant extract on the WiDr cancer cell line on day 12 , which was $81.72 \mu \mathrm{g} / \mathrm{ml}$, was almost similar to that of the previous study which reported that the $\mathrm{IC}_{50}$ value of the supernatant extract against the WiDr cancer cell line was $88.88 \mu \mathrm{g} / \mathrm{ml}$, as the result of the fermentation of $T$. reese $i$ TV221 fungi for 11 days (Setyowati et al., 2018a).

The results of the cytotoxic test on the Vero cell line of the four extracts and positive control (5-FU) are shown in Figure 5, which showed the morphological photos of the Vero cell line given the highest $(1,000 \mu \mathrm{g} / \mathrm{ml})$ and lowest $(15.62 \mu \mathrm{g} / \mathrm{ml})$ concentrations. The higher concentration of sample will decrease the absorbance value which depicts the metabolic activity of living cells which is decreased. A decreased value of absorbance with increasing concentration of sample shows an increase in the number of cells that die and decreasing of number of live cells (Dwiandhono et al., 2020; 


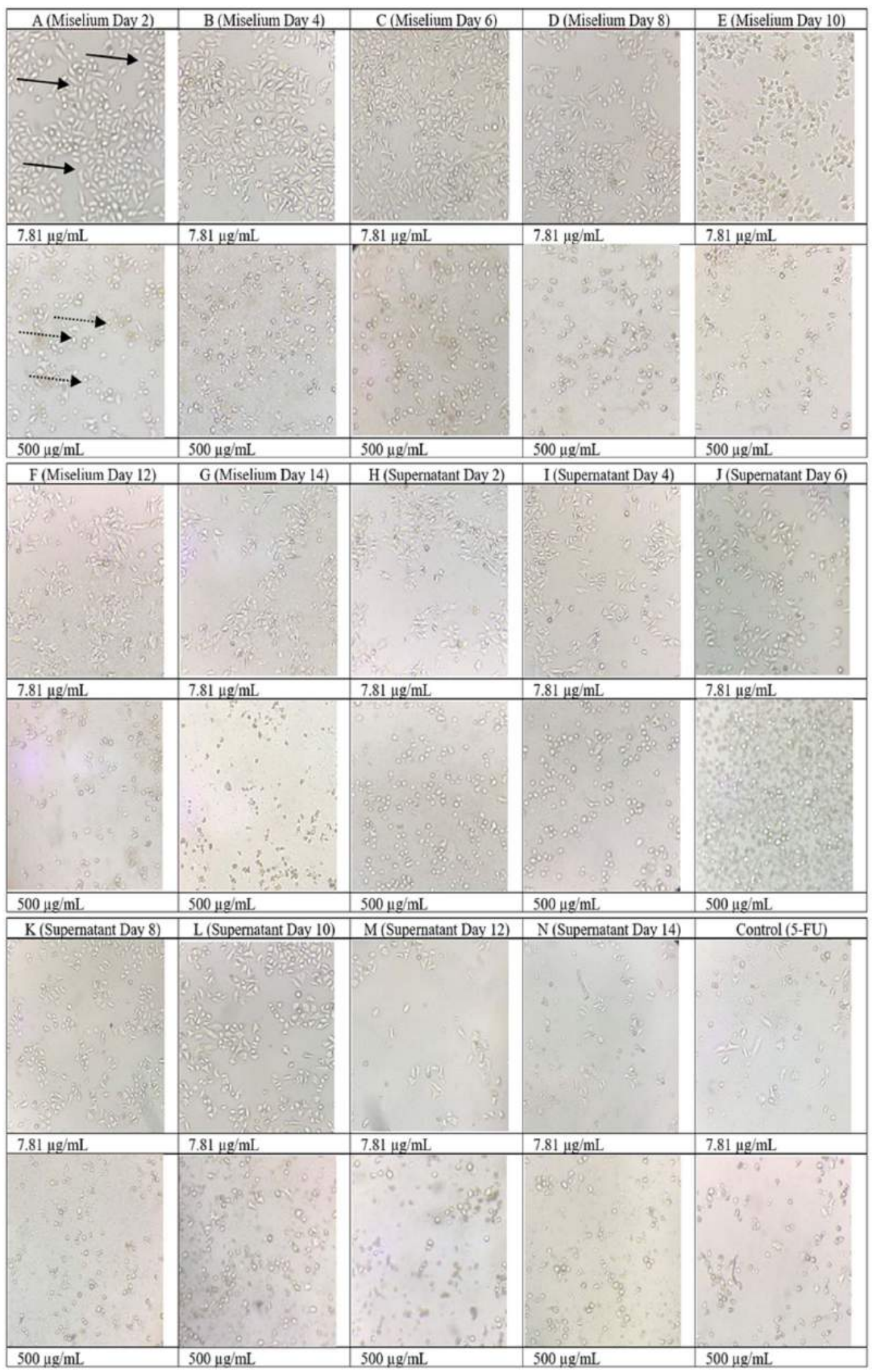

$\longrightarrow \quad$ : Living Cells ; $\cdots \cdots \cdot$ : Death Cells

Figure 4. The Morphology of The WiDr Cancer Cell Line When Given The Treated Samples at Doses of $7.81 \mu \mathrm{g} / \mathrm{mL}$ and $500 \mu \mathrm{g} / \mathrm{mL}$ 
Liu et al., 2011). In the cell morphology image, on average, at the highest dose of treatment, the Vero cell line died, marked by cell shrinkage, loss of cell nuclei, and not adhering to the surface. In the treatment at the lowest dose, the morphology of the Vero cell line looked like a dilated epithelial cell. The cell nucleus could be observed and attached to the base surface indicating that the cell line was still alive (Ammerman et al., 2008). The use of the Vero cell line aimed at seeing the effect of the sample on normal cells to determine whether the test substance could damage normal cells or not. Based on the data presented in Table 3, the $\mathrm{IC}_{50}$ value of the four extracts and the positive control (5-FU) had moderate cytotoxic activity against the Vero cell line. This shows that the

Table 2. $\mathrm{IC}_{50}$ values of the sample on the WiDr cancer cell line.

\begin{tabular}{ccc}
\hline Sample code & Specimen & IC $_{\mathbf{5 0}}(\boldsymbol{\mu g} / \mathbf{m l})$ \\
\hline A & Mycelium day 2 & 448.37 \\
B & Mycelium day 4 & 671.83 \\
C & Mycelium day 6 & $5,654.58$ \\
D & Mycelium day 8 & 746.67 \\
E & Mycelium day 10 & 366.45 \\
F & Mycelium day 12 & 262.05 \\
G & Mycelium day 14 & 206.51 \\
H & Supernatant day 2 & 255.61 \\
I & Supernatant day 4 & 205.63 \\
J & Supernatant day 6 & 139.68 \\
K & Supernatant day 8 & 154.29 \\
L & Supernatant day 10 & 231.19 \\
M & Supernatant day 12 & 81.72 \\
N & Supernatant day 14 & 81.93 \\
Control & 5-Fluorouracil & 24.99 \\
\hline & & \\
\hline
\end{tabular}

cytotoxic activity of the four extracts and the control on Vero cells did not cause severe damage to normal cells.

The SI value was determined by comparing the $\mathrm{IC}_{50}$ value in the Vero cell line with the $\mathrm{IC}_{50}$ value on the WiDr cancer cell line. The results of the SI values of the four extracts and the control are presented in Table 4. The sample was said to have high selectivity against a cancer cell if SI value $\geq 3$ (Badisa et al., 2009; Sutejo et al., 2016). The four extracts and the control (5-FU) had an SI value $>3$, meaning that the four supernatant extracts and 5-FU had high selectivity against WiDr cancer cells, so in the future it is very likely that they are developed as anticancer agents for colon cancer.

Referring to the antibacterial and cytotoxic activity of the supernatant and mycelium extracts, the active metabolites of $T$. reesei TV221 fungus began to be produced on day 2 of the fermentation as indicated by their biological activity. Active metabolites began to reach their peak production starting on day 6 and the peak occurred on day 12, indicated by the maximum antibacterial and cytotoxic activity. Therefore, T. reesei TV221 can be said to reach the highest active metabolites and activity. Trichoderma reesei TV221 should be fermented for 12 days. This is in line with the growth chart for the fungus which peaked on day 12 and then declined. In the growth phase of microorganisms, the peak of the stationary phase before the decline phase is the optimal state for a microorganism to produce active metabolites (Stanbury et al., 1995; Pratiwi, 2008).

Based on previous research, the metabolite groups found in the T. reesei fungus which is in symbiosis with the $S$. flabelliformis marine sponge are the cyclohexanone, phenol, and terpenoid group (Setyowati et al., 2017). This group of compounds has been shown to have a potential antimicrobial activity (Liu et al., 2013). In addition, the $S$. flabelliformis marine sponge has been known to produce jaspamide/jasplakinolide which has antibacterial and cytotoxic activity (Himaya et al., 2013; Liu et al., 2009; Setyowati et al., 2004, 2005). Many studies have linked the active compounds

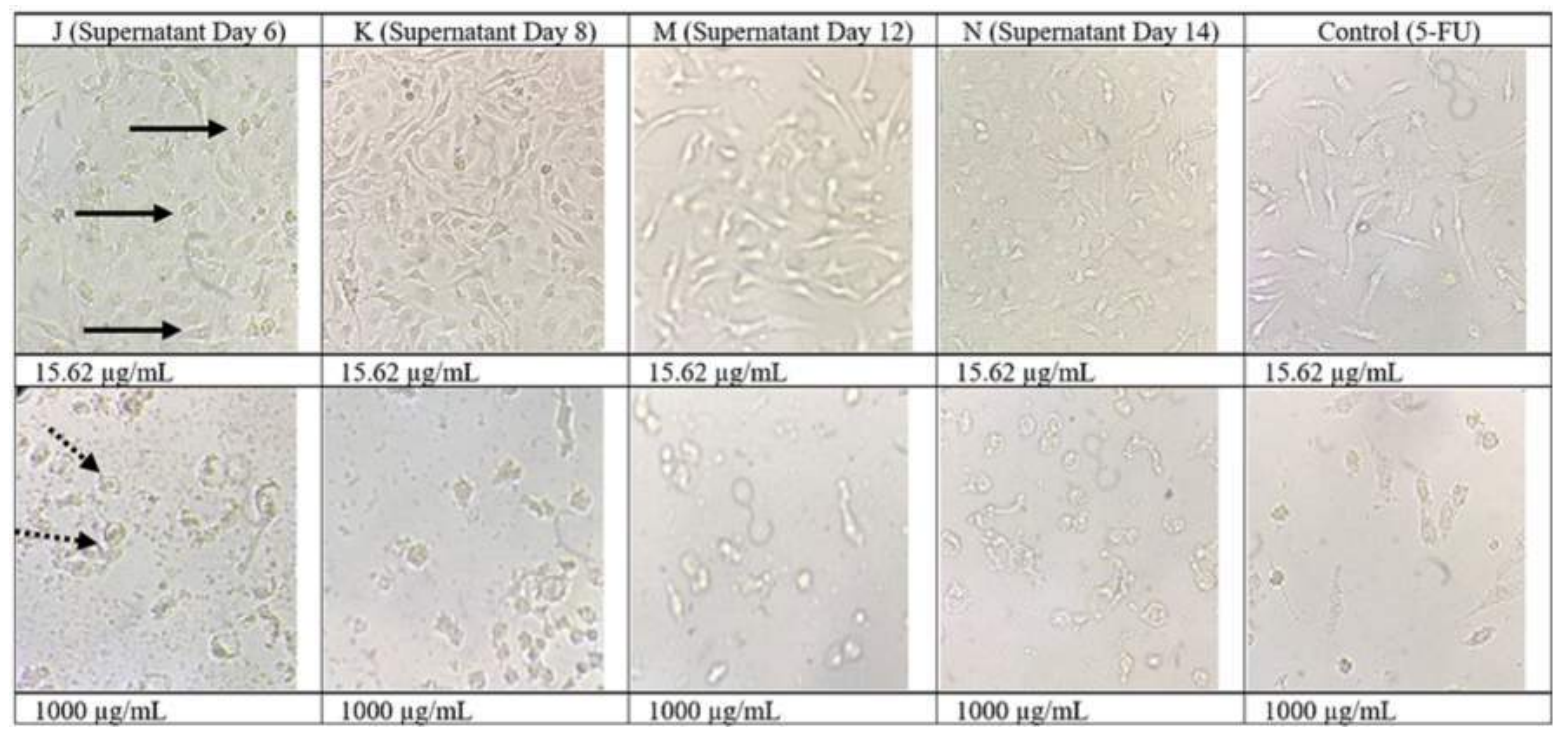

Figure 5. Morphology of the Vero cell line when given the treated samples at doses of $15.62 \mu \mathrm{g} / \mathrm{ml}$ and 1,000 $\mu \mathrm{g} / \mathrm{ml}$. $\longrightarrow$ : living cells; $\rightarrow$ dead cells. 
Table 3. $\mathrm{IC}_{50}$ values of the sample on the Vero cell line.

\begin{tabular}{ccc}
\hline Sample code & Specimen & IC $_{\mathbf{5 0}}(\boldsymbol{\mu g} / \mathbf{m l})$ \\
\hline J & Supernatant day 6 & 464.76 \\
K & Supernatant day 8 & 838.96 \\
M & Supernatant day 12 & 388.47 \\
N & Supernatant day 14 & 393.30 \\
Control & 5-Fluorouracil & 391.31 \\
\hline
\end{tabular}

Table 4. SI of cytotoxic activity on the WiDr cancer cell line.

\begin{tabular}{ccc}
\hline Sample code & Specimen & SI \\
\hline J & Supernatant day 6 & 3.33 \\
K & Supernatant day 8 & 5.44 \\
M & Supernatant day 12 & 4.75 \\
N & Supernatant day 14 & 4.80 \\
Control & 5-Fluorouracil & 15.66 \\
\hline
\end{tabular}

produced by sponges and their symbionts, and some have concluded that these active compounds are produced by symbionts found in marine sponge bodies. There are even some metabolites that have a similar structure between sponges and their symbionts (Hooper et al., 2002). This shows that the symbionts present in the sponge's body play an important role in the production of metabolites produced by marine sponges. Therefore, it is necessary to conduct further research on the antibacterial and cytotoxic activity of the active compounds of the $T$. reesei TV221 symbiont from the $S$. flabelliformis marine sponge.

\section{CONCLUSION}

The growth of the $T$. reesei TV221 fungus reaches its peak on day 12 and produces the highest amount of extract on day 10 of the fermentation. The T. reesei TV221 fungus has antibacterial activity against $E$. coli ATCC 25922 and $S$. aureus ATCC 25923 in both supernatant and mycelium extracts fermented with seawater at concentrations of $30 \mathrm{ppt}$, especially on days 6 and 12. Supernatant extracts on days 12 and 14 have cytotoxic activity on the WiDr cancer cell line which is classified as strong cytotoxic effect and has high selectivity on the WiDr cancer cell line as indicated by SI value $>3$. Based on the activity shown by the supernatant and mycelium extracts, it is likely that the active metabolites of the $T$. reesei TV221 fungus begin to be produced on day 2 and reach their peak on day 12. Active metabolites that have antibacterial and cytotoxic activity are estimated to be the cyclohexanone, phenol, and terpenoid groups. Based on its activities, in the future the extract from the fermentation of the T. reesei TV221 fungus has the potential to be developed as an antibacterial and anticancer agent, especially for colon cancer.

\section{ACKNOWLEDGMENTS}

The author would like to acknowledge the funding support from PDUPT-DIKTI Indonesia 1622/UN1/DITLIT/DITLIT/PT/2021.

\section{AUTHOR CONTRIBUTIONS}

All authors made substantial contributions to conception and design, acquisition of data, or analysis and interpretation of data; took part in drafting the article or revising it critically for important intellectual content; agreed to submit to the current journal; gave final approval of the version to be published; and agree to be accountable for all aspects of the work. All the authors are eligible to be an author as per the international committee of medical journal editors (ICMJE) requirements/guidelines.

\section{CONFLICTS OF INTEREST}

The authors report no financial or any other conflicts of interest in this work.

\section{ETHICAL APPROVALS}

This study does not involve experiments on animals or human subjects.

\section{PUBLISHER'S NOTE}

This journal remains neutral with regard to jurisdictional claims in published institutional affiliation.

\section{REFERENCES}

Ammerman NC, Beier-Sexton M, Azad AF. Growth and maintenance of vero cell lines. Curr Protoc Microbiol, 2008; 4(SUPPL. 11):1-7.

Badisa RB, Darling-Reed SF, Joseph P, Cooperwood JS, Latinwo LM, Goodman CB. Selective cytotoxic activities of two novel synthetic drugs on human breast carcinoma MCF-7 cells. Anticancer Res 2009; 29(8):2993-6.

Balouiri M, Sadiki M, Ibnsouda SK. Methods for in vitro evaluating antimicrobial activity: a review. J Pharm Anal, 2016; 6(2):71-9.

Bheemaraya PMB, Ramesh YST, Amaresh YS, Naik MK. Salinity stress tolerance in native Trichoderma isolates. Environ Ecol, 2013; 31(2A):727-9.

Brinkmann CM, Marker A, Kurtböke DI. An overview on marine sponge-symbiotic bacteria as unexhausted sources for natural product discovery. Diversity, 2017; 9(40):1-31.

Cancer Chemoprevention Research Center. Standar procedure for cytotoxic test method MTT. Cancer Chemoprevention Research Center, Yogyakarta, Indonesia, 2019.

Davis WW, Stout TR. Disc plate method of microbiological antibiotic assay. II. Novel procedure offering improved accuracy. Appl Microbiol 1971a; 22(4):666-70.

Davis WW, Stout TR. Disc plate method of microbiological antibiotic assay. I. Factors influencing variability and error. Appl Microbiol 1971b; 22(4):659-65.

Debbab A, Aly AH, Proksch P. Bioactive secondary metabolites from endophytes and associated marine derived fungi. Fungal Divers, 2011; 49(1):1-12.

Dwiandhono I, Widodo HB, Wahyono DJ, Ratnaningtyas NI, Nawangtantrini G, Novrial D, Ashar F. The cytotoxic effect of Ganoderma lucidum ethanol extract on KB CCL-17 oral cancer cell culture. Indones J Biotechnol Med, 2020; 9(2):99-105.

Egan S, Thomas T, Kjelleberg S. Unlocking the diversity and biotechnological potential of marine surface associated microbial communities. Curr Opin Microbiol, 2008; 11(3):219-25.

Eltamany EE, Abdelmohsen UR, Ibrahim AK, Hassanean HA, Hentschel U, Ahmed SA. New antibacterial xanthone from the marine sponge-derived Micrococcus sp. EG45. Bioorganic Med Chem Lett, 2014; 24(21):4939-42.

Fadholly A, Ansori ANM, Jayanti S, Proboningrat A, Kusala MKJ, Putri N, Rantam FA, Sudjarwo SA. Cytotoxic effect of Allium cepa L. Extract on human colon cancer (widr) cells: in vitro study. Res J Pharm Technol, 2019; 12(7):3483-6.

Himaya SWA, Kim SK. Marine symbiotic microorganisms: a new dimension in natural product research. In: Kim, SK (ed.). Marine microbiology: bioactive compounds and biotechnological applications. 
1st edition, Wiley-VCH Verlag GmbH \& Co, New York, NY, pp 295-305, 2013.

Hooper JNA, Van Soest RWM. Systema porifera. A guide to the classification of sponges. Kluwer Academic, Plenum Publisher, New York, NY, 2002, vol 1.

Janakiraman V, Govindarajan K. Cytotoxic potency of bioactive metabolites from an endophytic fungi Pestaloptiopsis breviseta against MCF-7 and A 549 cancer cell lines. Res J Pharm Technol, 2020; 13(10):4683

Lee YK, Lee J, Lee HK. Minireview: microbial symbiosis in marine sponges. J Microbiol, 2001; 39(4):254-64.

Liu L, Liu S, Chen X, Guo L, Che Y. Pestalofones A-E, bioactive cyclohexanone derivatives from the plant endophytic fungus Pestalotiopsis fici. Bioorganic Med Chem, 2009; 17(2):606-13.

Liu RM, Zhong JJ. Ganoderic acid $\mathrm{Mf}$ and $\mathrm{S}$ induce mitochondria mediated apoptosis in human cervical carcinoma HeLa cells. Phytomedicine, 2011; 18(5):349-55.

Liu Y, Zuo S, Zou Y, Wang J, Song W. Investigation on diversity and population succession dynamics of endophytic bacteria from seeds of maize (Zea mays L., Nongda108) at different growth stages. Ann Microbiol, 2013; 63(1):71-9.

Masi G, Marcucci L, Loupakis F, Cerri E, Barbara C, Bursi S, Allegrini G, Brunetti IM, Murr R, Ricci S, Cupini S, Andreuccetti M, Falcone A. First-line 5-fluorouracil/folinic acid, oxaliplatin and irinotecan (FOLFOXIRI) does not impair the feasibility and the activity of second line treatments in metastatic colorectal cancer. Ann Oncol, 2006; 17(8): 1249-54.

Mishra N, Khan SS, Sundari SK. Native isolate of Trichoderma: a biocontrol agent with unique stress tolerance properties. World J Microbiol Biotechnol, 2016; 32(130):1-23.

Niyomkam P, Kaewbumrung S, Kaewnpparat S, Panichayupakaranant P. Antibacterial activity of Thai herbal extracts on acne involved microorganism. Pharm Biol, 2010; 48(4):375-80.

Pelczar MJ, Chan ECS. Microbiology fundamental I. 1st edition, UI-Press, Jakarta, Indonesia, 2008a.

Pelczar MJ, Chan ECS. Microbiology fundamental II. 2nd edition, UI-Press, Jakarta, Indonesia, 2008b.

Pratiwi SUT. Pharmaceutical microbiology. Erlangga, Jakarta, Indonesia, 2008.

Proboningrat A, Muhammad AN, Ansori, Fadholly A, Putri N, Kusala MKJ, Achmad AB. First report on the cytotoxicity of Pinus merkusii bark extract in WiDr, a human colon carcinoma cell line. Res J Pharm Technol, 2021; 14(3):1685-8.

Rungprom W, Siwu ERO, Lambert LK, Dechsakulwatana C, Barden MC, Kokpol U, Blanchfield JT, Kita M, Garson MJ. Cyclic tetrapeptides from marine bacteria associated with the seaweed Diginea sp. and the sponge Halisarca ectofibrosa. Tetrahedron, 2008; 64(14):3147-52.

Samirana PO, Murti YB, Jenie RI, Setyowati EP. Marine spongederived fungi: fermentation and cytotoxic activity. J Appl Pharm Sci, 2020; 11(01):21-39.

Sangavi R, Gopinath P, Kumar A. Antibacterial activity of ethanolic extract of cinnamon against clinical isolates of Staphylococcus aureus. Res J Pharm Technol, 2019; 12(1):259-61.

Setyowati EP, Pratiwi SUT, Hertiani T, Samirana O. Bioactivity of fungi Trichoderma reesei, associated with sponges Stylissa flabelliformis collected from National Park West Bali, Indonesia. J Biol Sci, 2017; 17(8):362-8.

Setyowati EP, Sudarsono, Wahyuono S. Cytotoxicity and antimicrobial test of the bioactive compound isolated from Stylissa flabelliformis sponge. Indones J Pharm 2004;15(2):50-6.

Setyowati EP, Pratiwi SUT, Purwantiningsih, Purwantini I. Invitro cytotoxicity and apoptosis mechanism of ethyl acetate extract from Trichoderma reesei strain TV221 associated with marine sponge: Stylissa flabelliformis. J Appl Pharm Sci, 2018a; 8(9):151-7.
Setyowati EP, Pratiwi SUT, Purwantiningsih, Samirana PO. Antimicrobial activity and Identification of fungus associated Stylissa flabelliformis sponge collected from Menjangan Island West Bali National Park, Indonesia. Indones J Pharm, 2018b; 29(2):66-73.

Setyowati EP, Sudarsono, Wahyuono S. Jaspamide : structure identification of cytotoxic and fungicide compound from Stylissa flabelliformis sponges. Indones J Pharm, 2005; 16(1):12-9.

Setyowati EP, Purwantiningsih, Erawan FMY, Rahmanti S, Hanum NR, Devi NCM. Cytotoxic and antimicrobial activities of ethyl acetate extract from fungus Trichoderma reesei strain JCM 2267 , Aspergillus flavus strain MC- 10-L, Penicillium sp, and Aspergillus fumigatus associated with marine sponge Stylissa flabelliformis. Research J Pharm Tech, 2021; 14(10), 5126-32

Shahid SM, Umar N. Spectrum of antimicrobial susceptibility of Eschericia coli and Staphylococcus aureus isolates from clinical samples. Res J Pharm Tech, 2015; 8(10):1399.

Shalini DS, Sreenivasulu Y, Bhaskar Rao K V. Talaromyces verruculosus, a novel marine fungi as a potent polyhydroxybutyrate degrader. Res J Pharm Tech, 2014; 7(4):433-8.

Sharmalkumar M, Arunagirinathan N, Anand D, Girivasan KP, Baskar M, Rameshkumar MR, Elumalai A, Kumar MR. In-vitro study on antimicrobial and anticancer activities of marine sponge Clathria frondifera associated bacteria. Res J Pharm Technol, 2020; 13(8):3753.

Sibero MT, Radjasa OK, Sabdono A, Trianto A, Triningsih DW, Hutagaol ID. Antibacterial activity of indonesian sponge associated fungi against clinical pathogenic multidrug resistant bacteria. J Appl Pharm Sci, 2018; 8(2):088-94.

Stanbury PF, Whitaker A, Hall SJ. Principles of fermentation technology. 2nd édition, Elsevier Ltd., London, UK, 1995.

Suman T, Kaleeswaran B, Immanuel T, Dam Roy S, Krishnan P. Antibacterial activity of Pseudoceratina purpurea - a marine sponge from Andaman. Res J Pharm Technol, 2013; 6(5):544-9.

Sutejo IR, Putri H, Meiyanto E. The selectivity of ethanolic extract of buah makassar (Brucea javanica) on in vitro study of metastatic breast cancer. J Agromedicine Med Sci, 2016; 2(1):1-5.

Taylor MW, Radax R, Steger D, Wagner M. Sponge-associated microorganisms: evolution, ecology, and biotechnological potential Microbiol Mol Biol Rev, 2007; 71(2):295-347.

Thoms C, Schupp PJ. Chemical defense strategies in sponges: a review. In: Custódio MR, Lôbo-Hajdu G, Hajdu E, Muricy G (eds.) Porifera research: biodiversity, innovation and sustainability, IMOS Gráfica e Editora, Rio de Janeiro, Brazil, pp 627-37, 2007.

Tjay TH, Rahardja K. Important drugs: efficay, use, and side effect. 7th edition, PT. Elex Media Komputindo, Jakarta, Indonesia, 2015.

Ukhty N, Tarman K, Setyaningsih I. Isolation of endophytic fungi from the coastal plant terong pungo (Solanum sp.) and its antibacterial activity against oral pathogenic bacteria. Biotropia (Bogor), 2017; 24(1) $9-15$.

Weerapreeyakul N, Nonpunya A, Barusrux S, Thitimetharoch T, Sripanidkulchai B. Evaluation of the anticancer potential of six herbs against a hepatoma cell line. Chin Med, 2012; 7(15):1-7.

How to cite this article:

Samirana PO, Murti YB, Jenie RI, Setyowati EP. Antibacterial and cytotoxic activities of supernatant and mycelium extracts from fermentation of fungal symbiont Trichoderma reesei TV221. J Appl Pharm Sci, 2021; 11(12):090-099. 